\title{
Prospective use of Graphitized Steels in Mechanical Engineering
}

\author{
Kuis D.V. \\ Belarusian state technological University, \\ Republic of Belarus, Minsk;
}

\author{
Akimov I.V. \\ Zaporizhzhya national technical university, \\ Ukraine, Zaporozhye; \\ Volchok I.P. \\ Zaporizhzhya national technical university, \\ Ukraine, Zaporozhye; \\ Svidunovich N.A. \\ Belarusian state technological University, \\ Republic of Belarus, Minsk;
}

\author{
Belsky S.E. \\ Belarusian state technological University, \\ Republic of Belarus, Minsk;
}

Lezhnev S.N.

Karaganda state industrial University, Kazakhstan, Temirtau

sergey_legnev@mail.ru

Tolkushkin A.O.

Karaganda state industrial University, Kazakhstan, Temirtau

\begin{abstract}
Graphitized steel in some cases, due to its intermediate position in composition and properties between low-carbon steel and cast iron, can provide the necessary combination of properties of structural material. They are successfully replace ductile iron, carbon and low-alloy steel in the manufacture of critical parts of machines and mechanisms.
\end{abstract}

Keywords: graphitized steels, alloying elements, mechanical engineering.

\section{INTRODUCTION}

Graphitized steel are usually hypereutectoid alloys in which a part or all of the carbon in the form of graphite inclusions. Due to inclusion of graphite, which serves as a lubricant and increases the thermal conductivity of steels which are used as wear-resistant materials (stamp for cold stamping, drawing tools, beater, balls and armor lining plates of coal mills, shot blasters casing and blade, sandblasters nozzles, etc.) as well as for the manufacture of parts operating in the temperature cycling loads (casting molds, ingot molds, glass-forming tool, furnace equipment parts, etc.). Taking into account the good damping capacity, low sensitivity to stress concentrators and a relatively high mechanical properties of graphitized steel, they are successfully replace ductile iron, carbon and low-alloy steel in the manufacture of critical parts of machines and mechanisms.

\section{RESEARCH METHODOLOGY}

According to [1], major alloying elements in graphitized steels are: carbon $(1,2-1,6 \%)$, silicon $(0,75-$ $2,5 \%)$ and manganese $(0,2-1,2 \%)$. Also nickel, molybdenum, copper, aluminum and titanium find application [2, 3]. Steels of the above composition have good casting properties: high fluidity, low linear shrinkage and low tendency to form hot and cold cracks. Heat treatment of steels normally consists of two stages: annealing at $850-950^{\circ} \mathrm{C}$ for the decay of secondary cementite and graphite phase formation and annealing at $700-780^{\circ} \mathrm{C}$ for forming the structure of the metal base. As a result of appropriate technological methods (ladle inoculation, increased content of silicon and other) could achieve a complete graphitization of excess eutectoid carbon and obtaining a structure of pearlite graphite without the use of heat treatment.

As noted above, the graphite inclusions give graphitized steel anti-friction properties, increase their damping capacity and reduce sensitivity to stress concentrators. On the other hand, increasing amounts of graphite phase, strength and ductility indicators are reduced. In paper [4] estimated influence of the graphite phase at the mechanical properties of the alloys with increasing carbon content. Between the amount of graphite and the strength of the alloys were observed linear dependence: increasing amount of carbon from 0.48 to $4.02 \%$ and, accordingly, the amount of graphite inclusions from 2.1 to 12.3 vol. $\%$ led to a decrease of tensile strength from $652 \mathrm{MPa}$ to $168 \mathrm{MPa}$ at room temperature; from $511 \mathrm{MPa}$ to $152 \mathrm{MPa}$ and from 155 $\mathrm{MPa}$ to $48 \mathrm{MPa}$ at temperatures of $500^{\circ} \mathrm{C}$ and $700^{\circ} \mathrm{C}$ respectively. The hardness was decreased from HB220 to HB121 (Fig. 1).

The amount of graphite phase had a significant influence on the wear rate in terms of friction of metal on metal with slippage under load $50 \mathrm{~N}$ : with increasing the amount of carbon and decreasing the distance between inclusions of graphite wear rate decreased. At the location of the graphite phase in the form of dendritic colonies, when the distance between the inclusions is practically reduced to a minimum, the wear rate was minimal due to 
the lubricating effect of the graphite. With increasing carbon content of more than $2.5 \%$ was observed the decrease of wear resistance, due to embrittlement and chipping of metal near large inclusions of graphite.

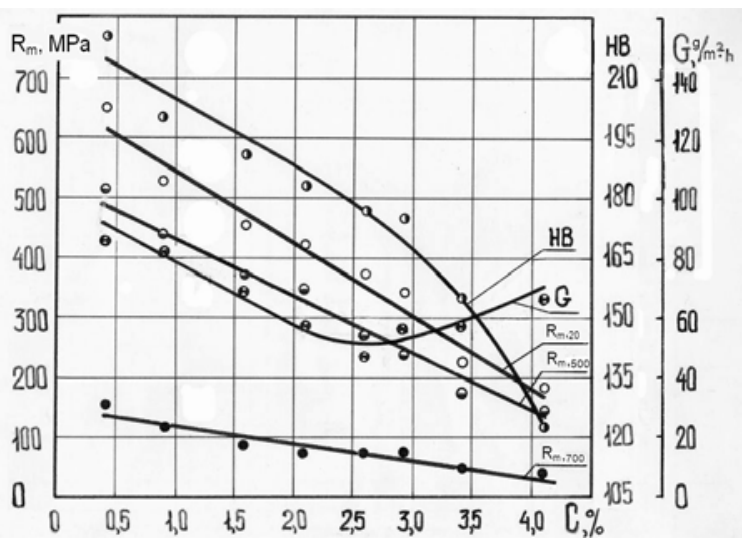

Fig. 1. Influence of carbon on tensile strength $R_{m}$ at $20^{\circ} \mathrm{C}, 500^{\circ} \mathrm{C}$ and $700^{\circ} \mathrm{C}$, on hardness $\mathrm{HB}$ and durability $\mathrm{G}$ of iron-carbon alloys

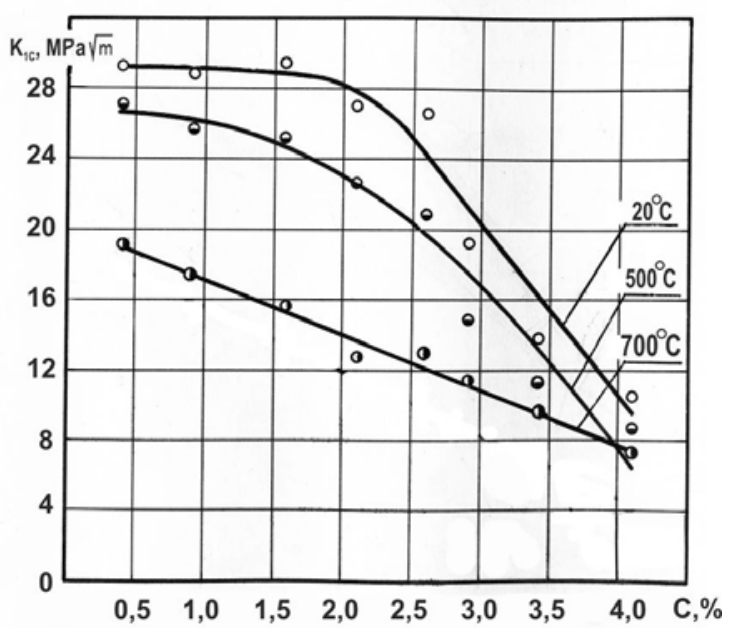

Fig. 2. The influence of carbon on fracture toughness $\mathrm{K}_{1 \mathrm{C}}$ of iron-carbon alloys at 20,500 and $700^{\circ} \mathrm{C}$
Somewhat different results were obtained when testing for the crack resistance (Fig. 2). With increasing carbon content up to $1,51 \%$ fracture toughness $\mathrm{K}_{1 \mathrm{C}}$ at a temperature of $20^{\circ} \mathrm{C}$ remained unchanged, at $500^{\circ} \mathrm{C}$ declined slightly; higher concentrations of carbon leads to a sharp reduction of this indicator. At a test temperature of $700^{\circ} \mathrm{C}$ was a linear inverse relationship between the carbon content and $\mathrm{K}_{1 \mathrm{C}}$

Overall, the results presented above show that the graphitized unalloyed steels in strength, hardness, fracture toughness and wear resistance is approximately twice higher than those of gray iron and ductile.

\section{RESEARCH RESULTS AND DISCUSSION}

Further increase of the mechanical and service properties of graphitized steels can be achieved by alloying. In paper [2] investigated the effect of doping of $\mathrm{Mn}, \mathrm{Cr}, \mathrm{Ni}$ and $\mathrm{Mo}$ on the structure and mechanical properties of graphitized steels modified with aluminum. For this purpose in 120-pound induction furnace with a basic lining steel with base chemical composition was smelted: $1,38 \ldots 1,40 \% \mathrm{C} ; 0,85 \ldots 0,90 \% \mathrm{Si} ; 0,26 \ldots 0,28 \% \mathrm{Al}$; $0,029 \ldots 0,031 \% \mathrm{P} ; 0,022 \ldots 0,027 \% \mathrm{~S}$. Alloying elements were changed in the ranges shown in the table 1 . The liquid metal was poured into the dry sand-clay molds. The resulting casting were subjected to graphitized annealing at $850^{\circ} \mathrm{C}$ for three hours, followed by annealing nodularisation, providing $\alpha \leftrightarrow \gamma$ conversion. As shown by metallographic analysis, in all variants of steels the inclusion of graphite were in the form of small $(10 \ldots 40 \mu \mathrm{m})$ evenly distributed spherical precipitates and vermicular form (Fig. 3 a), when the metallic matrix was almost entirely represented by a granular perlite (Fig. 3 b). With increasing content of alloying elements monotonically increases strength, hardness and yield strength, while decreasing elongation (Table 1).

TABLE 1. THE CONTENT OF ALLOYING ELEMENTS IN THE COMPOSITION OF THE GRAPHITIZED STEEL AND MECHANICAL PROPERTIES

\begin{tabular}{|c|c|c|c|c|c|c|c|c|c|}
\hline \multirow{2}{*}{ 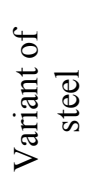 } & \multicolumn{4}{|c|}{ Amount of alloying elements } & \multicolumn{5}{|c|}{ Mechanical properties } \\
\hline & $\mathrm{Mn}, \%$ & $\mathrm{Cr}, \%$ & $\mathrm{Ni}, \%$ & Mo, $\%$ & $\mathrm{R}_{\mathrm{m}}, \mathrm{MPa}$ & $\mathrm{R}_{0,2}, \mathrm{MPa}$ & $\delta, \%$ & $\mathrm{HB}$ & $\mathrm{K}_{1 \mathrm{C}}, \mathrm{MPa} \cdot \sqrt{\mathrm{m}}$ \\
\hline 1 & 0,80 & - & - & - & 418 & 288 & 8,3 & 195 & 33,9 \\
\hline 2 & 0,80 & 0,30 & - & - & 582 & 334 & 7,6 & 197 & 38,3 \\
\hline 3 & 0,80 & 0,30 & 1,2 & - & 697 & 348 & 7,5 & 217 & 40,6 \\
\hline 4 & 1,80 & 0,30 & 1,2 & - & 775 & 433 & 5,0 & 241 & 39,8 \\
\hline 5 & 1,80 & 0,30 & 1,2 & 0,32 & 917 & 479 & 4,5 & 255 & 36,6 \\
\hline 6 & 1,80 & 0,60 & 1,2 & 0,32 & 920 & 525 & 3,0 & 255 & 34,7 \\
\hline
\end{tabular}




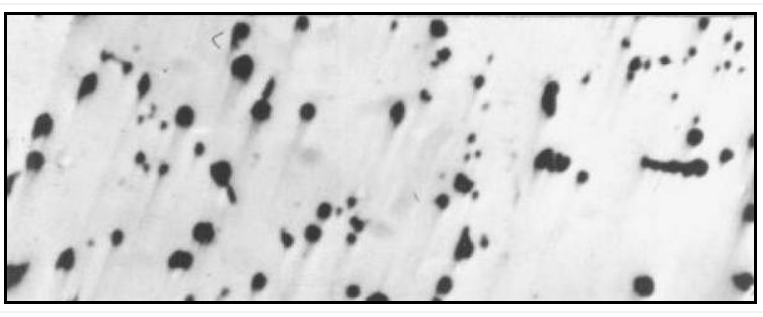

a

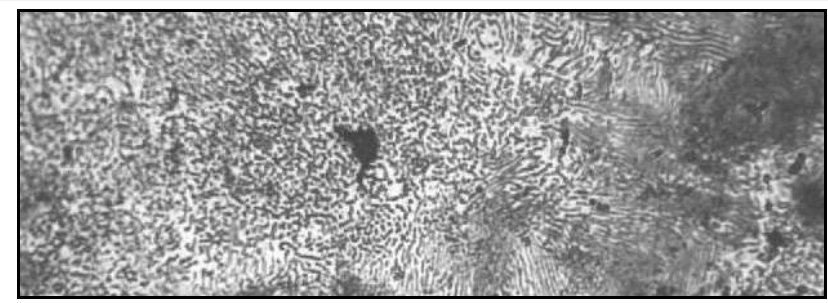

$\mathrm{b}$

Fig. 3. The typical structure of the steel after heat treatment $(a-$ not etched $\times 100 ; b-$ etched $\times 500)$

This change of the properties can be explained by solid solution hardening of the metal matrix with alloying elements. The critical stress intensity factor was changed from $33,9 \mathrm{MPa} \cdot \sqrt{\mathrm{m}}$ to $40,6 \mathrm{MPa} \cdot \sqrt{\mathrm{m}}$ and had a maximum value for steel of 3 rd variant, complex alloyed $0,8 \% \mathrm{Mn} ; 0,3 \% \mathrm{Cr}$ and $1,2 \% \mathrm{Ni}$.

Thus, alloying with manganese, chromium, Nickel and molybdenum improves the mechanical properties of graphitized steel in solid solution hardening. It is established that graphitized steel with composition: $1,38 \ldots 1,40 \% \mathrm{C} ; \quad 0,85 \ldots 0,90 \% \mathrm{Si} ; \quad 0,7 \ldots 0,8 \% \mathrm{Mn}$; $0,25 \ldots 0,3 \% \mathrm{Cr} ; \quad 1,0 \ldots 1,2 \% \mathrm{Ni} ; \quad 0,25 \ldots 0,28 \% \mathrm{Al}$; $0,029 \ldots 0,031 \% \mathrm{P} ; 0,022 \ldots 0,027 \% \mathrm{~S}$ after graphitizing and subsequent annealing nodularisation had a stress intensity factor $\mathrm{K}_{1 \mathrm{C}}=40 \ldots 45 \mathrm{MPa} \cdot \sqrt{\mathrm{m}}$, which is almost 1.5 times higher than characteristics in ferrite-pearlite ductile iron.

\section{SUMMARY}

The results show that the graphitized steel in some cases, due to its intermediate position in composition and properties between low-carbon steel and cast iron, can provide the necessary combination of properties of structural material, for example, the thermal conductivity and strength for metal forms, resistance to wear - for parts operating under conditions of dry friction and, consequently, to improve the reliability and durability of machine parts of metallurgical and mechanical engineering industry.

\section{REFERENCES}

[1] Todorov R.P., Nikolov M.V. Structure and properties of castings made of graphitized steel. - M.: Metallurgy, 1976.-168 p.

[2] I.Andreyko, I. Volchok, O. Ostash, I. Akimov, B. Kulik. Strength and cyclic crack resistance of low-alloy graphitized steel // Fracture mechanics strength and materials structures: Comp. scient. works.- Lviv, 2004. - P.691-696. - 1997. - №4. - p.35-36.

[3] Yakovlev A.Y., Volchok I.P. Materials for the manufacture of metal forms // Casting and metallurgy. - 2007. - № 4. P. 118-121.

[4] Kolotilkin O.B. Development of materials for glass-forming equipment in view of silicate melts: Abstract of cand. of techn. sciences thesis/ Physico-Mechanical Institute named after G.V. Karpenko NAS Ukraine - Lviv, 2004. - 36 p. 